MA MOMIR NINKOVIĆ, doktorand

Filozofski fakultet, Univerzitet u Beogradu

Beograd, Republika Srbija

momirninkovic22@gmail.com

originalan naučni rad

UDK: 327(497.1:4)"1948"

primljeno: 8. decembar 2017.

339.92(497.1:47)"1948"

prihvaćeno: 16. maj 2018.

341.7:929 Црнобрња Б.

https://doi.org/10.29362/ist20veka.2018.2.nin.117-138

\title{
MISIJA BOGDANA CRNOBRNJE U MOSKVI I PITANJE ODUSTAJANJA OD TRGOVINSKIH PREGOVORA ZA 1948. GODINU
}

APSTRAKT: $U$ članku je, kroz tok $i$ ishod misije Bogdana Crnobrnje u Moskvi, razmatrano pitanje odustajanja od trgovinskih pregovora između Jugoslavije i Sovjetskog Saveza za 1948. godinu. Prikazani su početni stavovi obe strane u pregovorima i kako se postepeno pod uticajem politike, u jednom osetljivom periodu, menjalo sovjetsko držanje prema jugoslovenskim zahtevima. Nastojali smo da ukažemo i na određene posledice ovakve sovjetske odluke na privredne prilike u Jugoslaviji, kao i da rasvetlimo pitanja $u$ vezi sa kasnijim sovjetskim negiranjem izjave Alekseja Krutikova od 26. februara 1948. Rad je zasnovan na neobjavljenim dokumentima arhiva u Republici Srbiji i Ruskoj Federaciji, objavljenim zbirkama dokumenata, memoaristici i stručnoj istoriografskoj literaturi.

KLJUČNE REČI: Jugoslavija, Sovjetski Savez, 1948, trgovinski pregovori, spoljna trgovina, Bogdan Crnobrnja, Milovan Đilas, Anastas Ivanovič Mikojan, Aleksej Dmitrijevič Krutikov

Imajući u vidu uzroke, tok, posledice i različite aspekte sukoba Federativne Narodne Republike Jugoslavije (FNRJ, Jugoslavija) sa Savezom Sovjetskih Socijalističkih Republika (SSSR, Sovjetski Savez), možemo se složiti sa rečima Branka Petranovića koji je za „1948“ govorio da je u pitanju „blok orijaških razmera“. ${ }^{1}$ Ovaj sukob, koji je bio jedna od najvećih „,vododelnica“ u jugoslovenskoj istoriji, imao je ogromne posledice na jugoslovensku spoljnopolitič$\mathrm{ku}$ orijentaciju u godinama Hladnog rata i na unutrašnje prilike u Jugoslaviji tokom narednih decenija. ${ }^{2}$ Šire posmatrano, imao je veliki uticaj na prirodu od-

\footnotetext{
${ }^{1}$ Бранко Петрановић и Сава Даутовић, Велика шизма. Четрдесетосма (Подгорица: ЦИД, 1999), 14.

${ }^{2}$ Исто, 7-8, 16-17, 58-59, 68, 71-72; Слободан Селинић, „Југословенско-совјетски преговори, децембар 1947-фебруар 1948. године. Прилог проучавању југословенско-совјетског сукоба 1948. године“, у: Међународни научни скуп Браничево у историји Србије. Зборник радова III. Свеска 6, уредник Драган Алексић (Пожаревац: Историјски архив Пожаревац, Београд:
} 
nosa unutar socijalističkog lagera i uneo je ,veoma ozbiljne promene u opšti obris blokovske konfrontacije na međunarodnoj sceni, posebno u Evropi““3 $\mathrm{O}$ sim državne, partijske, ideološke, političke, vojne, kulturne, personalne (sukob vođa), sukob iz 1948. imao je i ekonomsku dimenziju. ${ }^{4} \mathrm{U}$ jugoslovenskoj interpretaciji događaja, ekonomskim odnosima dve države i njihovom mestu u izbijanju sukoba pridavana je veća težina nego što su ih oni imali. Najizrazitije se to vidi na primeru mešovitih jugoslovensko-sovjetskih akcionarskih društva. ${ }^{5}$ Trgovinska razmena dve države nije izazivala toliko kontroverzi kao mešovita društva, ali je postojalo određeno nezadovoljstvo na obe strane. ${ }^{6}$

Институт за новију историју Србије, 2008), 600; Ljubodrag Dimić, Jugoslavija i Hladni rat. Ogledi o spoljnoj politici Josipa Broza Tita (1944-1974) (Beograd: Arhipelag, 2014), 121-122, 129.

${ }^{3}$ Leonid Gibianskii, ,Sovjetsko-jugoslovenski sukob 1948: istoriografske verzije i novi arhivski izvori“, u: Jugoslavija v hladni vojni, Zbornik z znanstvenega posveta Jugoslavija v hladni voj$n i$, Ljubljana, 8.-9.maja 2000. ur. Jasna Fischer i dr. (Ljubljana: Inštitut za novejšo zgodovino, Toronto: University, 2004), 27.

${ }^{4}$ Милан Терзић, Михајло Басара и Дмитар Тасић, „Увод“, у: Информбиро и Југословенска (народна) армија. Зборник докумената, прир. М. Терзић, М. Басара и Д. Тасић (Београд: Службени гласник, 2015), 10.

${ }^{5} \mathrm{Na}$ primer, Vladimir Dedijer je pišući o ovim društvima i jugoslovensko-sovjetskom sukobu, čitavu celinu knjige „Izgubljena bitka J. V. Staljina“ naslovio sa „Srž sukoba: ekonomski odnosi“" (Vladimir Dedijer, Izgubljena bitka J. V. Staljina (Beograd: Izdavačka organizacija „Rad“, 1978), 93-123). Iako su postojali različiti pogledi i nesuglasice u vezi sa osnivanjem i funkcionisanjem ovih društava (Момир Нинковић, „Неуспешни преговори о организацији југословенско-совјетских мешовитих друштава (1945-1947)“, Токови историје, бр. 2, (2015), 129), arhivski dokumenti ne potvrđuju ,verziju o velikom uticaju takvih nesuglasica ni na praktične odnose Moskve i Beograda, niti na opšte mišljenje sovjetske strane o jugoslovenskom režimu“ (L. Gibianskii, „Sovjetsko-jugoslovenski sukob 1948...“, 35).

${ }^{6}$ Široko posmatrano, glavni razlog nesporazuma i nerazumevanja proisticao je iz „sudara“ idealizovanih predstava jugoslovenskih komunista o SSSR-u i njegovoj ekonomskoj snazi i objektivnih sovjetskih mogućnosti. Opširnije: Момир Нинковић, „Успостављање и одвијање редовних економских односа између Југославије и Совјетског Савеза 1945. године“, у: 1945. Крај или нови почетак?, Тематски зборник радова, гл. и одг. ур. Зоран Јањетовић (Београд: Институт за новију историју Србије, Музеј жртава геноцида, 2016), 509-510. Uže gledano, do konkretnih problema u robnoj razmeni dolazilo je pri sprovođenju sporazuma o uzajamnim isporukama. Ministar spoljne trgovine Nikola Petrović je u svojim sećanjima o tome pribeležio: „Sama priroda naših trgovinskih sporazuma sa Sovjetskim Savezom je takva da dovodi do zaoštravanja odnosa. Izvršenje trgovinskih sporazuma prepušteno je u Sovjetskom Savezu i kod nas trgovinskoj operativi, to znači našim i sovjetskim spoljnotrgovinskim preduzećima, a ona poslovima pristupaju rukovođena poslovnom logikom i uz to i sama zavise od proizvođača u Sovjetskom Savezu i kod nas. Prema tome, reč je o komercijalnim poslovima, gde se i s jedne is druge strane zahteva strogo poštovanje ugovorenih količina i rokova. Samom prirodom stvari to dovodi do stalnih trzavica, pa i do neželjenih zaoštravanja.“ (Dušan Popović, Letopis o Vlaovićima, III (Novi Sad: Agencija MiR, 2006), 143). Bilo je u poslovanju jugoslovenskih i sovjetskih preduzeća zaista takvih slučajeva koji su, rečima službenika Jugodrva, „nažalost“ pokazivali „da i među rođenom braćom dolazi do nesuglasica, kada se ulazi u poslovne odnose, a da se prethodno ne napravi čist račun" (Arhiv Jugoslavije (AJ), fond 9, Ministarstvo spoljne trgovine Vlade FNRJ, fascikla 184, Jugodrvo - Trgovinskom izaslanstvu FNRJ Moskva, 19. 5. 1947). Ta „neželjena zaoštravanja“ su nekada dobijala ozbiljne razmere - dobar primer za to je ,žalba Ministarstva spoljne trgovine SSSR na neprijateljski i neuobičajeni ton dopisivanja našeg 'Centroproma', koji je označen sa strane jednog višeg službenika toga Ministarstva kao jedinstven u istoriji poslovnih veza Ministarstva spoljne trgovine SSSR sa inostranstvom“ (Diplomatski arhiv Ministarstva spoljnih poslova Republike Srbije, Poli- 
Spolja posmatrano, početkom 1948. godine odnosi dve države delovali su skladno i Beograd je doživljavan kao najodaniji sledbenik Moskve. Međutim, period na koji se odnosi tema rada (sredina januara - početak marta), predstavlja poslednju fazu onoga što se u literaturi naziva ,prikrivenom“ fazom sukoba. Iz ove faze sukoba postepeno se, u martu 1948, prešlo u otvoren sukob, koji je sredinom godine internacionalizovan i postao javan. Činjenica da je ovaj period neposredno prethodio otpočinjanju otvorenog sukoba daje dodatnu važnost razgovorima i pregovorima koje su jugoslovenski i sovjetski politički, vojni i ekonomski predstavnici vodili u Moskvi prvih meseci 1948. godine. Za razliku od političkih i vojnih pregovora koji su temeljno obrađeni $\mathrm{u}$ istoriografiji (a zastupljeni su i u memoaristici i zbornicima dokumenata), ${ }^{7}$ ekonomski pregovori koje je u istom periodu, paralelno, vodio pomoćnik ministra spoljne trgovine FNRJ Bogdan Crnobrnja, ${ }^{8}$ nisu bili

tička arhiva, 1946, SSSR, fascikla 78, dosije 2, 11580, V. d. šefa III odseka Nikola Engler - Načelniku političkog odeljenja, 5. 9. 1946. Opširnije o ovom slučaju, „tonu prepiske“ Centroproma sa sovjetskim Tehnoeksportom i istrazi koja je u vezi sa tim sprovedena: AJ, 9-186, Centroprom Tehnoeksportu, 26. 7. 1946; Isto, 9-189, Trgovinski izaslanik - Kabinetu ministra spoljne trgovine, 4. 10. 1946; Isto, Trgovinski izaslanik - Ministarstvu spoljne trgovine, 16. 10. 1946; Isto, Centroprom - Kontrolnom odeljenju Ministarstva spoljne trgovine, 11. 9. 1946; Isto, Centroprom - Kontrolnom odeljenju Ministarstva spoljne trgovine, 31. 8. 1946; Isto, Izveštaj Zorana Budišina ministru spoljne trgovine - o tonu dopisivanja Centroproma sa Tehnoeksportom, 29. 8. 1946). Međutim, problemi do kojih je dolazilo u poslovnim odnosima ,trgovinskih operativa“ dve države nisu ostavili ozbiljniji trag na političke odnose dve države.

${ }^{7}$ O jugoslovensko-sovjetskim odnosima početkom 1948, političkim i vojnim pregovorima, opširnije: L. Gibianskii, „Sovjetsko-jugoslovenski sukob 1948...“, 27-47; Đoko Tripković, „Iza gvozdene zavese. Početak i eskalacija sukoba Tito-Staljin prvih meseci 1948“, Istorija 20. veka, br. 1, (1996), 89-99; С. Селинић, „Југословенско-совјетски преговори...“, 595-614; Milovan Đilas, Vlast i pobuna (Beograd: Književne novine, 1991), 126-144; Isti, Razgovori sa Staljinom (Beograd: Književne novine, 1990), 83-119; Edvard Kardelj, Borba za priznanje i nezavisnost nove Jugoslavije 1944-1957. Sećanja (Beograd: NIRO Radnička štampa, Ljubljana: Državna založba Slovenije, 1980), 111-120; Svetozar Vukmanović Tempo, Revolucija koja teče. Memoari, IV (Zagreb: Globus 1982), 14-25; Александар Животић, Југословенско-совјетске војне супротности (1947-1957). Искушења савезништва (Београд: Архипелаг, Институт за новију историју Србије, 2015), 81-104; Анатолий С. Аникеев, „Югославия в годы конфликта с СССР и странами «народной демократии»“, у: Москва и Восточная Европа. Советско-югославский конфликт и страны советского блока. 1948-1953 гг. Очерки истории, отв. ред. А. С. Аникеев (Москва: Институт славяноведения РАН, Санкт-Петербург: Нестор-История, 2017), 15-37; Југословенско-совјетски односи 1945-1956. Зборник докумената, прир. Љ. Димић и др. (Београд: Министарство спољних послова Републике Србије, 2010); Vladimir Dedijer, Dokumenti 1948, I (Beograd: Izdavačka radna organizacija „Rad“, 1979); Югославия в ХХ веке. Очерки политической истории, отв. ред. К. В. Никифоров (Москва: ИнСлав, Индрик, 2011), 567-582. O sastanku 10. februara, opširnije videti literaturu u napomeni 37.

${ }^{8}$ Bogdan Crnobrnja Tolja (Perna, 1916 - Beograd, 1998). Završio je Učiteljsku školu u Pakracu, a zatim studirao Filozofski fakultet u Zagrebu. Završio je Śkolu rezervnih oficira u Goraždu, u Vojsci Kraljevine Jugoslavije. „Naprednom studentskom pokretu“ pristupio je 1938, a član Komunističke partije Jugoslavije bio je od 1941. Kao potporučnik učestvovao je u Aprilskom ratu. Posle sloma vratio se u Pakrac i aktivno učestvovao u pripremi ustanka. U toku Drugog svetskog rata bio je politički komesar Prvog slavonskog partizanskog odreda, komandant Prve slavonske (XII udarne) brigade, komesar, zamenik komandanta i komandant III operativne zone, sekretar Oblasnog narodnooslobodilačkog odbora za Slavoniju, zamenik komandanta VI slavonskog korpusa. Tri puta je ranjavan u ratu, a demobilisan je 1945. u činu pukovnika. U periodu 1945-1946. bio je direktor Zavoda za vanredne 
predmet zasebnog istraživanja, niti su podrobnije razmatrani u sklopu obrade širih tema. Zbog ovoga u literaturi možemo naići na pogrešne podatke i o nekim osnovnim, formalnim stvarima u vezi sa njima - o vremenu održavanja pregovora ili o funkciji Crnobrnje. Tako, na primer, možemo pročitati da je ,godine 1947, u Moskvi, tokom privrednih pregovora Jugoslavije i SSSR-a, Crnobrnja bio prvi funkcioner FNRJ kome je visoki zvaničnik SSSR-a Anastas [Ivanovič] Mikojan direktno saopštio da od sovjetske privredne pomoći Jugoslaviji neće biti ništa“, ili da je B. Crnobrnja bio ,ministar spoljne trgovine FNRJ“. 9 Zbog otklanjanja ovih propusta, ali i upotpunjavanja predstave o pregovorima vođenim u Moskvi početkom 1948. godine (i uopšte o odnosima dve države u tom periodu), značaja koji je odluka o odustajanju od potpisivanja protokola o robnoj razmeni za 1948. imala za privredu Jugoslavije, rešavanja određenih nedoumica koje može da izazove kasnije sovjetsko negiranje izjave Alekseja Dmitrijeviča Krutikova od 26. februara (pominje se i u čuvenom pismu od 27. marta 1948) i uopšte zbog mogućnosti da se jasnije sagleda mesto ekonomije u sukobu dve države, mislimo da ova tema zaslužuje posebnu obradu. Kako bismo što potpunije prikazali temu iz naslova, nastojaćemo da u radu damo odgovore na pitanja koja nam se čine relevantnim: Koji motivi su rukovodili jugoslovensku stranu pri pokretanju pitanja pregovora za potpisivanje protokola o uzajamnim isporukama za 1948. godinu? Kakva je bila početna pozicija obe strane u razgovorima? Kako su politički odnosi dve države uticali na tok i ishod razgovora? Šta je za jugoslovensku stranu značilo odustajanje od potpisivanja protokola o robnoj razmeni za 1948? Kako je jugoslovensko rukovodstvo gledalo na ovu odluku? Zbog čega su na sovjetskoj strani negirali izjavu Krutikova od 26. februara?

nabavke, što je bilo ,jugoslovensko odeljenje“ za saradnju sa UNR-om (United Nations Relief and Rehabilitation Administration). U radu ove ustanove pokazao se, kako navodi ministar Nikola Petrović, kao „odličan organizator“. U periodu 1946-1951. obavljao je dužnost pomoćnika ministra spoljne trgovine FNRJ. Od 1951. do 1954. bio je pomoćnik ministra inostranih poslova E. Kardelja. Zatim je 1954-1958. bio ambasador u Indiji, Cejlonu i Avganistanu. Od 1958. do 1961. obavljao je dužnost državnog podsekretara u Saveznom sekretarijatu za inostrane poslove, a zatim je bio generalni sekretar predsednika republike J. B. Tita (1961-1967), pa ambasador u SAD (1967-1971). Bio je predsednik Odbora Veća republika i pokrajina za društveni plan i razvojnu politiku (1974-1978), predsedavao je i Odborom Veća republika i pokrajina za ekonomske odnose sa inostranstvom (1978-1982). Na zasedanju Interparlamentarne unije u Beču 1978. izabran je za predsednika Komiteta za nacrte rezolucija. Na 34. zasedanju Generalne skupštine OUN (1979) bio je izabran za predsednika Komiteta svih (Committee of the Whole). Imao je zapaženu ulogu u organizaciji i pripremi Titove posete Indiji (1954), poseti Nehrua Jugoslaviji (1955), pripremi Prve konferencije nesvrstanih u Beogradu (1961), kao član jugoslovenske delegacije na Drugoj konferenciji nesvrstanih u Kairu (1964), a dao je idejne okvire i praktično se angažovao u širenju ekonomskih odnosa Jugoslavije sa nesvrstanim državama. U više navrata je biran za narodnog poslanika. Bio je i delegat u Saboru SR Hrvatske i član: Saveznog saveta za međunarodne odnose, Saveta federacije, Glavnog odbora Socijalističkog saveza radnog naroda Jugoslavije i Centralnog komiteta SKJ. Nosilac je većeg broja jugoslovenskih i stranih odlikovanja. (Stanko Crnobrnja, „Bogdan Crnobrnja Tolja“, u: Neočekivana promjena. Kako je stvoren Pokret nesvrstanih. Dnevnički zapisi Bogdana Crnobrnje iz 1961. godine, ur. S. Crnobrnja (Beograd: Muzej istorije Jugoslavije, 2016), 13-18; Joco Tarabić, „Crnobrnja Bogdan”, u: Vojna enciklopedija, Drugo izdanje, 2, Brdo-Foa, (Beograd: izdanje Redakcije Vojne enciklopedije, 1971), 210; Ines Šaškor, „Crnobrnja, Bogdan”, u: Enciklopedija Jugoslavije, 3, Crn-Đ, (Zagreb: Jugoslavenski leksikografski zavod Miroslav Krleža, 1984), 57; D. Popović, n. d., 68-69).

${ }_{9}^{9}$ S. Crnobrnja, n. d., 14; А. Животић, Југословенско-совјетске војне супротности..., 95. 
Trgovinski izaslanik FNRJ u Moskvi Viktor Žiberna navodio je u izveštajima iz 1946. i 1947. kao jednu od najvećih poteškoća u ekonomskim odnosima dve države ,nepravovremeno pristupanje pregovorima i nepravovremeno zaključivanje sporazuma“. Zbog ,sistema planske privrede“ u SSSR-u, upozoravao je: „Da bi mogli zadovoljavati naše uvozne potrebe kao i plasirati naš izvoz potrebno je da sovjetski plan o tome vodi računa“, tj. neophodno je bilo ,pravovremeno predložiti naš plan razmene““. ${ }^{10}$ Imajući u vidu „,dosadašnju praksu“, V. Žiberna je sredinom decembra 1947. ukazivao da je ,u svim dosadašnjim pregovorima Jugoslavija [...] bila ona koja je istupala kao inicijator za zaključenje Sporazuma o isporukama robe i na osnovu jugosl. predloga vođeni su pregovori“ i da je „od jugosl. predloga zavisio [...] obim razmene robe i treba priznati da je sovjetska strana do sada $u$ glavnom prihvaćala naše predloge u pogledu obima i nomenklature razmene“. $\mathrm{Na}$ osnovu ovoga je savetovao da, jugoslovenska strana treba prema tome da predloži za sledeći vremenski period svoj predlog u pogledu nomenklature, obima i rokova isporuka“, posebno ističući: „U cilju obezbeđenja kontinuiteta isporuka ovaj predlog treba [da] bude predložen pravovremeno.“ Imajući u vidu „dinamiku“ pregovora iz prethodnih godina i činjenicu da je važeći protokol isticao 31. maja 1948, trgovinski izaslanik je predlagao da pregovori za zaključenje novog protokola počnu „,najkasnije u martu“ i da se ,najkasnije mesec dana pre početka pregovora dostave sovjetskoj strani orientacioni, a gde je to moguće i specificirani predlog uzajamnih isporuka robe“. ${ }^{11} \mathrm{Na}$ osnovu sugestija trgovinskog izaslanika, jugoslovenska strana je još u decembru 1947, preko trgovinskog predstavnika SSSR-a u FNRJ Ivana Mihajloviča Lebedeva, pokrenula pitanje pregovora o sklapanju protokola o uzajamnim isporukama za 1948. godinu, kao i pitanje povećanja isporuka određenih proizvoda preko količina dogovorenih protokolom od 5. juna 1947. Kako sovjetska strana nije imala ništa protiv ovoga, u januaru 1948. u Moskvu je upućen B. Crnobrnja da ,izvrši sve pripremne radnje, preda kontigentne liste i utvrdi tačan dan dolaska [jugoslovenske] delegacije“". ${ }^{12}$

Odabir pomoćnika ministra spoljne trgovine FNRJ B. Crnobrnje, jednog od prvih ljudi jugoslovenskog ,spoljnotrgovinskog aparata“ $\mathrm{i}$, ,jednog od začetnika jugoslovenske ekonomske diplomatije“, koji je, po svedočenju Milovana Đilasa, bio „energičan i vešt pregovarač“ $i$ uz to je znao ruski jezik i ranije učestvovao u pregovorima sa SSSR-om, govori o važnosti ovog pitanja za Jugoslaviju. ${ }^{13} \mathrm{~B}$.

\footnotetext{
${ }^{10}$ AJ, 9-184, Viktor Žiberna - Vojislavu Srzentiću, 18. 4. 1946; Isto, Nekoliko načelnih primedaba na trgovinske odnose između Jugoslavije i SSSR-a u 1945/46 g., mart 1947.

${ }^{11}$ AJ, 9-185, Trgovinski izaslanik - Ministarstvu spoljne trgovine FNRJ, 18. 12. 1947.

12 Российский государственный архив экономики (РГАЭ), Ф. 413 (Министерство внешней торговли СССР), Оп. 24, Д. 4323, Л. 21, Запись беседы Торгпреда СССР в Югославии Лебедева И. М. с Министром Внешней Торговли ФНРЮ М. Поповичем, состоявшейся 26 декабря 1947 г.; РГАЭ, Ф. 413, Оп. 24, Д. 4322, Л. 162, Запись беседы Заместителя Министра Внешней Торговли Союза ССР тов. Крутикова А. Д. с Заместителем Министра Внешней Торговли Югославии г-ном Црнобрня состоявшейся 26 февраля 1948 года; АЈ, 9-190, Beleška sa sastanka održanog 26 februara 1948. g. u Minvneštorgu.

${ }^{13}$ S. Crnobrnja, n. d., 14; M. Đilas, Vlast i pobuna, 133; РГАЭ, Ф. 413, Оп. 24, Д. 2772, Л. 214, Краткие сведения о членах Югославской торговой делегации и экспертах, 5. 4. 1947.
} 
Crnobrnja je u Moskvu stigao 9. januara 1948. ${ }^{14}$ Kako je po dolasku „„čekao“ i po pitanju spoljnotrgovinske razmene ${ }^{15}$ nije imao značajnije razgovore, po svedočenju M. Đilasa ,navalio je na mene da zajedno s njim posetim Mikojana“. Nastojeći da na taj način što pre pokrene razgovore, B. Crnobrnja se odlučio na ovaj čin imajući u vidu i specifičnu političku ,težinu“ M. Đilasa, tada jednog od vodećih jugoslovenskih komunista i člana Politbiroa Centralnog komiteta Komunističke partije Jugoslavije (CK KPJ). Rečima M. Đilasa, on je „,nastojao“ na ovome i „da bi naši zahtevi imali veću težinu i razgovor veću autoritativnost". ${ }^{16}$ I dokumenti potvrđuju ovu verziju - izveštavajući o prvom sastanku kod sovjetskog ministra spoljne trgovine Mikojana 19. januara 1948. Crnobrnja navodi: „Ovde nisam počinjao razgovore radi toga što smo čekali dolazak grupe drugova, koja je bila na putu, sve do njihovog dolaska“. Da je ovo čekanje bilo opravdano govori deo izveštaja u kome se za ,vođu grupe koja je stigla“, tj. Đilasa, kaže da je njegovo prisustvo na sastanku sa Mikojanom ,mnogo pomoglo“. ${ }^{17}$ Pre zajedničke posete Mikojanu, Đilas je prvog dana po dolasku na razgovoru kod Josifa Visarionoviča Staljina 17. januara 1948, pored Albanije i vojnih tema, pomenuo i ,privredna“ pitanja. Na traženje da u sledećoj godini Jugoslaviji bude isporučeno „120 hiljada tona gvožđa“", Staljin se složio ,da nam pomognu““. ${ }^{18}$

Sa M. Đilasom i ambasadorom Vladimirom Popovićem, B. Crnobrnja je 19. januara 1948. posetio A. Mikojana. Iz ovog razgovora se dobro vide polazne

14 Tačan datum dolaska B. Crnobrnje u Moskvu navodi se u dokumentu Trgovinskog izaslanstva FNRJ u Moskvi iz marta 1948. u kome se rezimiraju do tada urađene stvari po pitanju tehničke pomoći SSSR-a Jugoslaviji (AJ, 9-188, Tehnička pomoć - nekoliko podataka, 9. 3. 1948). U literaturi se njegov dolazak u Moskvu pogrešno pomera čak za više od mesec dana ranije. Tako V. Dedijer, na osnovu ed-memoara koji je B. Crnobrnja sastavio 20 godina kasnije za potrebe pisanja „Izgubljene bitke J. V. Staljina“, navodi da je Crnobrnja poslat u Moskvu ,početkom decembra 1947.“ (V. Dedijer, Izgubljena bitka J. V. Staljina, 130; Isti, Dokumenti 1948, I, 189).

15 Tokom gotovo dvomesečnog boravka u sovjetskoj prestonici (9. januar-3. mart 1948), B. Crnobrnja je pored najvažnijeg pitanja svoje misije - proširenje spoljnotrgovinske razmene i potpisivanje novog protokola - vodio ili učestvovao u razgovorima i pregovorima i o potpisivanju sporazuma o tehničkoj saradnji dve države, predaji dodatne količine sovjetskih trofejnih vagona Jugoslaviji (preko količina dogovorenih sporazumom od 23. avgusta 1947), nabavci sovjetskih filmova, regulisanju spornih „transportnih“ pitanja, strukturi robne razmene sa „sovjetskom okupacionom zonom u Nemačkoj“, zajmu od 60 miliona dolara (u devizama ili zlatu), razmatranju pitanja „likvidacije“ jugoslovenske zaduženosti po „nerobnim plaćanjima“ i pitanju produženja sporazuma „o međusobnom stavljanju na raspoloženje novčanih sredstava za izdržavanje diplomatskih pretstavništava, i o drugim nerobnim plaćanjima“.

${ }^{16}$ M. Đilas, Razgovori sa Staljinom, 107; Isti, Vlast i pobuna, 133. Zbog prisustva M. Đilasa na dva sastanka sa Mikojanom u literaturi se pogrešno navodi da je on bio na čelu ,jugoslovenske delegacije“ koja je vodila trgovinske pregovore. (B. Petranović, Istorija Jugoslavije. Treća knjiga. Socijalistička Jugoslavija 1945-1988 (Beograd: Nolit, 1988), 203; С. Селинић, „Југословенскосовјетски преговори...”, 608; Исти, „Југословенска амбасада у СССР-у 1944-1949. Политичке прилике и партијски живот“, у: Србија и Русија 1814-1914-2014. Међународни научни скуn 13-14. октобар 2014, ур. Михаило Војводић (Београд: Српска академија наука и уметности, 2016), 280; Lj. Dimić, $n$. d., 117). Nikakva delegacija, kao takva, zapravo nije postojala, a učestvovanje M. Đilasa u razgovorima se objašnjava gore navedenim razlozima.

${ }^{17}$ AJ, 9-190, Razgovori u Moskvi, B. Crnobrnja, 20. 1. 1948.

18 AJ, fond 836, Kancelarija maršala Jugoslavije (KMJ), I-3-b/651, Telegram Milovana Đilasa, 19. 1. 1948; Југословенско-совјетски односи 1945-1956, 243, документ 106. 
osnove obe strane, jugoslovenski zahtevi (i potrebe koje ih motivišu) za povećanje isporuka određenih sovjetskih proizvoda i sklapanje protokola o razmeni za 1948; i kako je sovjetska strana, odnosno sovjetsko Ministarstvo spoljne trgovine (MST), u odnosu na svoje mogućnosti, gledalo na ta pitanja. Đilas je na početku razgovora izjavio da je za ostvarenje petogodišnjeg plana za Jugoslaviju neophodno ,širenje trgovine sa Sovjetskim Savezom“. Kao želju jugoslovenske strane naveo je da robna razmena u 1948. bude u vrednosti od najmanje 80 miliona dolara „sa obe strane“, u odnosu na 53 miliona dolara u 1947. godini. Govoreći o potrebama jugoslovenske privrede, istakao je nekoliko stvari, od kojih je najvažnija bila uvoz „dopunske količine“ crnih metala, odnosno „metalnih sirovina“ (,sirovo željezo“, brodski limovi, crni i beli tanki limovi, ,profili“", ,betonsko željezo“ - armatura). Jugoslovenska metalurška industrija nije imala dovoljno različitih tipova metala za mašinogradnju, naročito zbog toga što su 1947. godine bile „izgrađene i puštene u proizvodnju 4 nove fabrike mašina“, a u toku iste godine proizvedeno je „samo oko 420.000 tona“ čelika. Kako nisu uspeli pokušaji da se do „metalnih sirovina“ dođe iz Engleske i Čehoslovačke, jugoslovenska strana se nadala da će nesklad između proizvodnje crne metalurgije i proizvodnih kapaciteta i potrebe mašinogradnje uspeti da prevlada uvozom sirovina iz SSSR-a. Pored mašinogradnje, velika količina metala bila je potrebna za građevinarstvo. Mikojan je obećao da će ovo pitanje biti razmotreno i da će dobiti odgovor ,do konca nedelje“. Pri tom je naveo da „sirovo željezo mogu dati, za brodske limove će se takođe postarati da dadu. Postoji mogućnost $\mathrm{i}$ isporuke crnih tankih limova. Teškoća će biti sa betonskim željezom, profilima i belim limom.“ Đilas je posle razgovora telegramom javio utiske za traženih 120.000 tona „gvožđa“: „Mikojan je uveče rekao da će pola dati. Ja ću tražiti [ponovo] prijem kod Mikojana sa Crnobrnjom i Vladom Popovićem i insistirati na našim zahtevima. Mislim da ćemo ipak uspeti da pomaknemo na 100 hiljada tona.“ Pored „metalnih sirovina“, najviše pažnje je posvećeno nafti i naftnim derivatima. Navodeći da su obustavljene isporuke $\mathrm{UNRE}^{19}$ koje su pokrivale deo jugoslovenskih potreba $\mathrm{i}$ da su „Englezi uskratili snabdevanje brodova te radi toga tražimo $75.000 \mathrm{t}$ mazuta“, Mikojanu je predočeno ,da pored ugovorenih 80.000 t nafte i derivata tražimo dopunsku količinu za 1948 god. od 255.000 t". Mikojan je odgovorio da će biti „teškoća sa mazutom“.

Jugoslovenski pregovarači su tražili i dodatne količine pamuka (pored dogovorenih 12.000 tona, tražena je još 21.000 tona), hemijskih sirovina ( $\mathrm{u}$ vrednosti od 8 miliona dolara), ,kugellagera“ - odnosno kugličnih ležajeva (do 100.000 komada) i guma za automobile (62.000 kompleta). Sovjetski ministar spoljne trgovine je za većinu traženog odgovarao da „mogu dati“, ostavljajući da se preciziraju količine. Pozitivno je odgovoreno i na jugoslovensku molbu da „se svi ugovoreni metali isporuče u prvom kvartalu“. Đilas je od Mikojana tražio i „načelno mišljenje“ o pitanju „mogućnosti dolaska oko 10. februara o. g.

\footnotetext{
${ }^{19} \mathrm{O}$ isporukama UNRE Jugoslaviji, opširnije: B. Petranović, „Pomoć UNRE Jugoslaviji“, Istorija XX veka, Zbornik radova, II, odg. ur. Dragoslav Janković (Beograd: Institut za savremenu istoriju, 1961), 163-224.
} 
jugoslovenske trgovinske delegacije u Moskvu za trgovinske pregovore o uzajamnim isporukama robe u 1948. godini“". Prema jugoslovenskim izvorima, Mikojan je „na ovo pristao“ i ,saglasio se da trgovinski razgovori počnu oko 10 februara“. I sovjetska beleška sa razgovora ovo potvrđuje: „Mikojan je saopštio da on lično nema ništa protiv dolaska trgovinske delegacije u februaru“. S druge strane, Mikojan je skrenuo pažnju na tri pitanja: 1) nezadovoljavajući tempo isporuka pre svega kudelje, ali i kalcinirane sode; 2) visoku cenu kaustične sode; 3) da svu količinu obojenih metala namenjenu prodaji za „slobodnu valutu“ Jugoslavija prodaje SSSR-u. Pitanja koja je pomenuo Mikojan ukazuju da sovjetska strana $\mathrm{u}$ tom trenutku $\mathrm{u}$ ekonomskim odnosima, posebno $\mathrm{u}$ robnoj razmeni, dve države nije videla postojanje većih problema. ${ }^{20}$

Kako se Mikojan saglasio da isporuči većinu proizvoda za koje je jugoslovenska strana pokazala interes (ostalo je da se dogovore količine), zatim da u kratkom, sa jugoslovenske strane predloženom, roku otpočnu pregovori za sklapanje novog protokola za robnu razmenu u 1948. godini, a izašao je u susret i ostalim jugoslovenskim molbama i zahtevima, stav jugoslovenskih pregovarača je bio: „Opšti utisak nakon prvog sastanka jeste taj da razumeju naše poteškoće i trebovanja i da ćemo u mnogome uspeti““. ${ }^{21}$ Javljajući ministru spoljne trgovine o rezultatima razgovora kod Mikojana, Crnobrnja je završio telegram rečima: „Mislimo da će uglavnom sve ići“ ${ }^{22}$ A Đilas je telegrafisao: „Vlado i Crnobrnja kažu da je Mikojan ovog puta bio mekši nego inače“". 23

Dva dana kasnije, 21. januara, B. Crnobrnja se sreo sa Mikojanovim zamenicima Ivanom Fjodorovičem Semičasnovim i Sergejem Aleksandrovičem Borisovim. Na ovom „,radnom sastanku“ koji je trajao gotovo tri sata, na prvom mestu su razmatrana pitanja u vezi sa ,transportom robe morskim putem“. Usputno su dotaknuta i pitanja o potpisivanju ,novog protokola o isporukama robe“. Dogovoreno je da se delegati jugoslovenskih preduzeća „što brže povežu sa sovjetskim objedinjenjima u cilju rasmatranja specifikacija i rešavanja tekućih pitanja“; da se ubrza izdavanje viza za trojicu delegata koji su bili spremni za dolazak u Moskvu; i, najvažnije, Semičasnov se saglasio sa željom koju je izneo Crnobrnja - da se ,isporuke nekih proizvoda počnu realizovati ne posle 31. maja 1948. godine, kada se završava važenje starog Sporazuma, već odmah posle potpisivanja ugovora“. Zbog velikih

${ }^{20}$ Opširnije o sastanku 19. januara: РГАЭ, Ф. 413, Оп. 24, Д. 4322, Л. 170-174, Запись беседы Министра Внешней Торговли СССР тов. МИКОЯНА А. И. с представителем Югославского Правительства ДЖИЛАС М. от 19 января 1948г; АJ, 9-190, Razgovori u Moskvi, B. Crnobrnja, 20. 1. 1948; Isto, Beleška sa sastanka sa Mikojanom 19. januara 1948; AJ, KMJ, I-3-b/653, Izveštaj pomoćnika ministra spoljne trgovine FNRJ B. Crnobrnje o toku pregovora sa SSSR-om, 3. 4. 1948.

${ }^{21}$ AJ, 9-190, Razgovori u Moskvi, B. Crnobrnja, 20. 1. 1948.

${ }_{22}$ AJ, 9-189, Tolja, Minspoltrg - Ministru, 20. 1. 1948.

${ }^{23}$ Prepis ovog telegrama M. Đilasa u fondu Kancelarija maršala Jugoslavije je pogrešno datiran. Verovatno pri sređivanju fonda, na njemu je rukom napisan datum 21. 2. 1948. U tom periodu M. Đilas je već bio u Jugoslaviji. Sadržaj telegrama jasno pokazuje da je u njemu reč o sastanku kod Mikojana 19. januara, kao i da je napisan 20. januara (,Juče smo ja, Vlado i Crnobrnja bili kod Mikojana“"). Poslan je ili primljen 21. januara 1948. (AJ, KMJ, I-3-b/651, Telegram M. Đilasa, 21. 1. 1948). 
unutrašnjih potreba Jugoslavije, ovakva mogućnost paralelnog vršenja robne razmene u prvoj polovini 1948. godine - po Protokolu od 5. jula 1947. i po „,novom protokolu“ - imala je za jugoslovensku stranu veliki značaj. Kao i na prethodnom razgovoru diskusija i razmatranje svih pomenutih pitanja su bili u duhu uzajamnog razumevanja, predusretljivosti i dobre volje da se nađu rešenja za sporne stvari. ${ }^{24}$

Nedelju dana kasnije, 28. januara, održan je sledeći sastanak Crnobrnje i Semičasnova. Iako je ton razgovora bio nepromenjen, već od ovog sastanka sovjetska strana je počela sa odugovlačenjem odgovora o bitnim pitanjima. Na pitanje jugoslovenskog pomoćnika ministra spoljne trgovine kada se može očekivati odgovor na pitanja „,o uzajamnim isporukama za 1948“, koja su postavljena na sastanku kod Mikojana, njegov sovjetski kolega je odgovorio da ,ne može još dati odgovor jer se pitanja još proučavaju. Biće potrebno još nekoliko dana da pričekamo. Rade i pripremaju odgovor na ceo spisak." I odgovori na još neka važna pitanja su bili u istom duhu. Dalji razvoj pregovora pokazuje da je ovo početna tačka od koje je krenulo neprestano, sistematsko sovjetsko odugovlačenje pregovora i izbegavanje

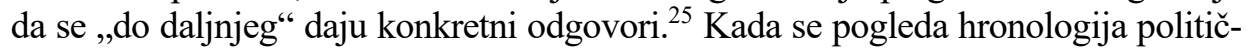
kih odnosa dve države ovaj zastoj su, po svemu sudeći, uzrokovali jugoslovenski potezi, preduzeti bez znanja Sovjeta, prema Albaniji i, šire posmatrano, poznata izjava Dimitrova od 17. januara o federalnom ili konfederalnom povezivanju istočnoevropskih država (računajući i Grčku!) čim se za to stvore uslovi. ${ }^{26}$

Naredni sastanak Crnobrnje i Semičasnova usledio je tri dana kasnije, 31. januara. Na ovom sastanku nastavljeno je sa „odlaganjem“ rešavanja najvažnijeg pitanja - Semičasnov je preneo: „Mikojan je izjavio da treba još malo pričekati jer su količine koje tražimo velike, mnogo veće nego što su oni planirali“ i da treba sve usaglasiti sa ,planskim organizacijama Sovjetskog Saveza“. Crnobrnja je Semičasnovu naglasio da će ,blagovremena isporuka tih proizvoda iz SSSR-a uticati na uspešno izvršavanje narodno-privrednog plana FNRJ““ ${ }^{27}$

24 РГАЭ, Ф. 413, Оп. 24, Д. 4322, Л. 187-190, Запись беседы Заместителя Министра Внешней Торговли СССР т. Семичастнова И. Ф. с Заместителем Министра Внешней Торговли Югославии г-ном Црнобрня, состоявшейся 21 января 1948 года; AJ, 9-189, Zapisnik (sa sastanka u Minvneštorgu), 23. 1. 1948.

25 AJ, 9-190, Beleška sa sastanka sa Semičastnovim 28. І. 1948 god.; РГАЭ, Ф. 413, Оп. 24, Д. 4322, Л. 175-178, Запись беседы заместителя министра внешней торговли СССР т. Семичастнова И. Ф. с заместителем министра внешней торговли Югославии г-ном Црнобрня, состоявшейся 28 января 1948 года.

${ }^{26}$ Opširnije o jugoslovensko-albanskim odnosima u ovom periodu, pitanju slanja jugoslovenske divizije u Albaniju i o izjavi Dimitrova od 17. januara: А. Животић, Југославија, Албанија и велике силе (1945-1961) (Београд: Архипелаг, Институт за новију историју Србије, 2011), 295-312; А. С. Аникеев, „Албания в политике Югославии и СССР в первые послевоенные годы по советским дипломатическим документам“, у: Ослобођење Београда 1944. Зборник радова, гл. и одг. ур. А. Животић (Београд: Институт за новију историју Србије, 2010), 475-487; Исти, „Югославия в годы конфликта с СССР...“, 20-27; С. Селинић, „Југословенско-совјетски преговори...“, 601-607; Югославия в XX веке, 573-574; Леонид Янович Гибианский, „К истории советско-югославского конфликта 1948-1953: Секретная советско-югославо-болгарская встреча в Москве 10 февраля 1948 года“, I, Славяноведение, но. 3, (1991), 13-18.

${ }^{27}$ Opširnije o sastanku Crnobrnje i Semičasnova 31. januara: AJ, 9-190, Beleška sa sastanka sa Semičastnovim 31. I. 1948 godine; РГАЭ, Ф. 413, Оп. 24, Д. 4322, Л. 3-5, Запись беседы Заместителя 
Poslednjeg dana januara Đilas je iz Moskve telegramom preneo Aleksandru Rankoviću utiske za „vojne“ i ,ekonomske“ pregovore: „Stvari su se ovde razvukle malo, iako su u početku krenule dobro. Konkretan odgovor nismo ni po čemu dobili, iako opšti izgledi nisu slabi.“ Mada je kasnije u svojim sećanjima pisao da je po dolasku Kardelja u Moskvu po pitanju „dogovora između albanske i jugoslovenske vlade o ulasku dveju jugoslovenskih divizija u Albaniju“ navodno ovom prebacivao i pitao: „A što vam je baš sada trebalo slanje divizija? I čemu sve to, sva ta nervozna uplitanja u Albaniju?“", u istom telegramu Đilas je naveo i: „Pitanje baze u Korči ću postaviti kad me bude primio drug Staljin. To će, nadam se, biti u toku iduće nedelje. Vi pripremajte sve, Rusi ne mogu biti protiv, javiću šta će reći, kad ih obavestim. “28 Međutim, u vremenu sve većeg zaoštravanja odnosa između Sovjetskog Saveza i Sjedinjenih Američkih Država, u uslovima sve veće polarizacije snaga, kada se išlo ka stvaranju dva suprotstavljena bloka ili lagera, kada se u sovjetskom lageru težilo sve većem monolitizmu, jačem povezivanju i kontroli nad komunističkim partijama i državama (reakcija na Trumanovu doktrinu i Maršalov plan), potpunoj ,sovjetizaciji“ i uspostavljanju stroge hijerarhije u odnosima, nije se moglo trpeti bilo šta što je „mirisalo“ na samostalnost ili neposlušnost. Politika samostalnog preduzimanja određenih spoljnopolitičkih koraka (stavljanja SSSR-a pred „svršen čin", kako su to na sovjetskoj strani govorili), uz uverenje da sovjetsko rukovodstvo „,ne može biti protiv“, nije mogla više da nailazi na sovjetsko tolerisanje. Jugoslovenska ,iskakanja“ u spoljnoj politici po pitanjima u neposrednom okruženju Jugoslavije, koja su mogla isprovocirati reakciju Zapada, krajem januara su izazvala oštru reakciju Moskve. ${ }^{29}$ Ministar inostranih poslova SSSR-a Vjačeslav Mihajlovič Molotov pisao je 31. januara Josipu Brozu Titu: „Vi smatrate normalnom situaciju u kojoj Jugoslavija, imajući ugovor o uzajamnoj pomoći sa SSSR, smatra da je moguće ne samo da se ne konsultuje sa SSSR o slanju svojih trupa u Albaniju nego ni da o tome naknadno ne obavesti SSSR“" i da su „potpuno slučajno“ saznali za odluku o slanju jugoslovenskih ,trupa“ u Albaniju. Navodeći da „ovakav način nije normalan“ i da se „SSSR ne može složiti s tim da bude doveden pred svršen čin“ i da ,ne može snositi odgovornost za posledice postupaka takve vrste“, sovjetski ministar je istakao: „očigledno je da između naših vlada postoje ozbiljna razmimoilaženja u shvatanju uzajamnih odnosa između naših zemalja, koje međusobno vezuju saveznički

Министра Внешней Торговли Союза ССР тов. Семичастнова И. Ф. с Заместителем Министра Внешней Торговли ФНРЮ г-ном Црнобрня, состоявшейся 31-го января 1948 года.

${ }_{28}$ AJ, KMJ, I-3-b/651, Telegram Đida - drugu Marku, 1. 2. 1948; M. Đilas, Vlast i pobuna, 135.

${ }^{29}$ Opširnije: Lj. Dimić, $n$. d., 116-117; Đ. Tripković, n. d., 89-99; С. Селинић, „Југословенскосовјетски преговори...“, 595-614; L. Gibianskii, „Sovjetsko-jugoslovenski sukob 1948...“, 27-47; А. С. Аникеев, Как Тито от Сталина ушел: Югославия, СССР и США в начальный период «холодной войны» (1945-1957) (Москва: Институт Славяноведения РАН, 2002), 3-8, 122-137; Исти, „Югославия в годы конфликта с СССР...“, 15-25; Никола Б. Поповић, „Сукоб Тито-Стаљин у светлу совјетизације Источне Европе“, у: Зборник радова са међународног округлог стола Тито-Стаљин, гл. и одг. ур. Миладин Милошевић (Београд: Архив Србије и Црне Горе, 2007), 95-108. 
odnosi“. Na sovjetskoj strani su, imajući u vidu ,napetost međunarodne situacije“, smatrali da „ozbiljna razmimoilaženja u spoljnopolitičkim pitanjima“ dve države treba „otkloniti“ na „nezvaničnom savetovanju u Moskvi“, zbog čega u sovjetsku prestonicu treba da dođu ,dva-tri odgovorna predstavnika jugoslovenske vlade“. ${ }^{30}$ Kako bi se otklonili nesporazumi, u Moskvu su ,radi specijalnih razgovora“" upućeni Edvard Kardelj i Vladimir Bakarić. ${ }^{31}$

Na sastanku Crnobrnje i Semičasnova poslednjeg dana januara, jugoslovenski predstavnik je zamolio da Mikojan primi Đilasa „u ponedeljak jer bi hteo što pre natrag“. Kao teme za razgovor Crnobrnja je naveo: ,odgovor na naš spisak uzajamnih isporuka, skraćenje rokova po Kreditnom sporazumu i isporuka vagona“ ${ }^{32}$ Zajedno sa Crnobrnjom i ambasadorom Popovićem, Đilas je posetio Mikojana 3. februara. Na početku kratkog, petnaestominutnog, razgovora Đilas je rekao da je ,cilj njegove posete drugu Mikojanu želja da dobije ukoliko je moguće odgovor na pitanja koja je on postavio u razgovoru 19. januara 1948. g. o povećanju robne razmene za 1948. godinu i mogućnosti dobijanja iz SSSR-a u 1948. godini sovjetske robe potrebne za ispunjenje petogodišnjeg plana Jugoslavije“". Mikojan je na ovo rekao da ,nije spreman da dâ odgovor na postavljena pitanja $i$ pretpostavlja da ovi odgovori mogu biti saopšteni gdinu Đilasu najranije kroz nedelju dana“. Iako je imao plan da se ,što pre“ vrati u Jugoslaviju, Đilas je posle ovakvog odgovora rekao da ,razume složenost rešavanja pitanja“ i da će se zbog toga ,zadržati u Moskvi još izvesno vreme da bi sačekao odgovor pošto su pitanja proširenja trgovine sa SSSR-om za Jugoslaviju veoma važna“" Ništa bolje odgovore Đilas nije dobio ni po ostalim pitanjima koja je postavio - sovjetski ministar je odgovarao da nije upućen ni nadležan da vodi takve razgovore. Poređenje beležaka dva razgovora Mikojana i Đilasa jasno pokazuje koliko su se mnogo za dve nedelje izmenili ton i držanje Anastasa Ivanoviča prema jugoslovenskim predstavnicima. $^{33}$ „Bilo je očevidno“ - kako se kasnije sećao Đilas: „točkovi sovjetske mašinerije ukočeni su prema Jugoslaviji“، 34

Dodatnu zabrinutost na jugoslovenskoj strani izazvale su vesti iz susedstva. Aleksandar Ranković je 6. februara javio Đilasu: „Danas imamo obaveštenje iz Rumunije da su tamo u širokom obimu forsirane glasine: Da je Maršal Tito pristupio Maršalovom planu, da je odbio da ide u Moskvu na savetovanje, da se Maršal Tito opredelio za američku politiku i posvadio sa Dimitrovim, na

${ }^{30}$ Opširnije o sovjetskoj reakciji i načinu na koji je J. B. Tito „krajnje uznemireno“ dočekao ovu vest: Југословенско-совјетски односи 1945-1956, 245-246, док. 108-110; А. С. Аникеев, „Югославия в годы конфликта с СССР...“, 25-26.

${ }^{31}$ AJ, KMJ, I-3-b/651, Telegram Marka - Drugu Đilasu, 2. 2. 1948.

${ }^{32}$ AJ, 9-190, Beleška sa sastanka sa Semičastnovim 31. I. 1948 godine; РГАЭ, Ф. 413, Оп. 24, Д. 4322, Л. 3-5, Запись беседы Заместителя Министра Внешней Торговли Союза ССР тов. Семичастнова И. Ф. с Заместителем Министра Внешней Торговли ФНРЮ г-ном Црнобрня, состоявшейся 31-го января 1948 года.

33 Opširnije o sastanku М. Đilasa i А. Mikojana: РГАЭ, Ф. 413, Оп. 24, Д. 4322, Л. 179-180, Запись беседы Министра Внешней Торговли СССР тов. МИКОЯНА А. И. с представителем Югославии г. ДЖИЛАС, 3 февраля 1948 года; Југословенско-совјетски односи 1945-1956, 247-248, док. 111.

${ }^{34}$ M. Đilas, Razgovori sa Staljinom, 108. 
koga je juče tobože izvršen atentat. Ove glasine su proširene u najširim slojevima Rumunije.“ Ističući da su te stvari ,zabrinjavajuće i treba ih rasčistiti“, Ranković je naglašavao ,da takve vesti nisu mogle poteći iz Jugoslavije jer ovde niko nije znao o pripremi savetovanja. Prema tome uzročnika treba tražiti u Sofiji, Rumuniji i Moskvi." Zbog težine i osetljivosti ovog pitanja, Ranković je uputio Đilasa na razgovor sa Kardeljem, kada ovaj stigne u Moskvu, a onda da „u najpogodnijoj formi govorite o tome na najvišem mestu“. 35

Očekivano, posle razgovora kod Mikojana i uz novonastale okolnosti, usledio je opšti ,zastoj“. Đilas je telegramom javio Titu: „U vezi s pregovorima nema ničeg naročitog novog i zato vam nijesam ni javljao. Sve stoji na mrtvoj tačci“, i ,stvar je u čekanju po svim linijama“. Govoreći o zastoju po pitanju ,vojnih isporuka“, Đilas je naveo: „Ja ću sačekati Kardelja pa ćemo stvar postaviti kod Molotova ili Staljina. To bih već učinio da Kardelj nije krenuo. Inače Rusi se mogu izgovarati da im zahtjevi nisu ranije dostavljeni na proučavanje. Ja mislim da su oni te stvari ostavili da pričekaju. Razlozi mi nisu poznati.“ Navedeno se u potpunosti može primeniti na ekonomske odnose. Rezimirajući kratko stvari „,u pogledu trgovine“, Đilas je naveo da su predali ,zahtjeve i ponude“, da je ,ponovo bio kod Mikojana s Crnobrnjom“ i da je sovjetski ministar rekao „,da je stvar u proučavanju, da mora da ide u sjednicu vlade i da zbog toga moramo čekati još nedelju dana“. Uprkos Mikojanovim rečima, Đilasov utisak je bio: „Ja ne verujem da će oni odgovoriti kroz nedelju dana, nego još kasnije“". Član jugoslovenskog Politbiroa očigledno nije telegramom hteo da javlja sve utiske i saznanja Titu, pa je navodeći da se Koča Popović vraća u Jugoslaviju, telegram završio sa: „Razgovaraj s njim i Tempom o svemu, pa će ti biti stvar jasna". ${ }^{36}$ Nekoliko dana kasnije jugoslovenske (Đilas, Kardelj i Bakarić) i bugarske predstavnike primilo je 10. februara u Kremlju sovjetsko rukovodstvo na čelu sa Staljinom. Na ovom ,trojnom sastanku“ kritikovani su određeni spoljnopolitički potezi i inicijative bugarskih i jugoslovenskih komunista (sklapanje jugoslovensko-bugarskog ugovora, izjava Dimitrova od 17. januara i slanje jugoslovenske divizije u Albaniju) i kao ,glavni zaključak“ navedena ,potreba stalnog konsultovanja po svim pitanjima spoljne politike“ sa SSSRom. „Diskusija je tekla tako da nismo mogli postaviti ni jedno od naših ekonomskih pitanja“, javljali su jugoslovenski rukovodioci. ${ }^{37}$

\footnotetext{
35 AJ, KMJ, I-3-b/651, Telegram Aleksandra Rankovića - Milovanu Đilasu, 6. 2. 1948. Otprilike $\mathrm{u}$ isto vreme pojavile su se i informacije o skidanju slika sa J. B. Titom u Rumuniji. M. Đilas, Vlast i pobuna, 142; V. Dedijer, Novi prilozi za biografiju Josipa Broza Tita, III (Beograd: Izdavačka radna organizacija „Rad“, 1984), 259.

${ }^{36}$ Југословенско-совјетски односи 1945-1956, 249-250, док. 112; AJ, KMJ, I-3-b/651, Telegram Đida -Titu, 11. 2. 1948. U fondu Kancelarija maršala Jugoslavije na telegramu se kao datum navodi 11. februar (datum kada je primljen?), a u zborniku dokumenata o jugoslovenskosovjetskim odnosima se navodi da je upućen iz Moskve 11. februara. Sadržaj telegrama jasno pokazuje da je morao biti napisan nekoliko dana pre toga, pre dolaska Kardelja i Bakarića u Moskvu (stigli rano ujutru 8. februara - Л. Я. Гибианский, „К истории советскоюгославского конфликта 1948-1953...“, I, 15).

${ }^{37}$ Opširnije o sastanku sovjetske, jugoslovenske i bugarske delegacije u Moskvi, 10. februara 1948, o potpisivanju protokola o obaveznim ,međusobnim konsultacijama o svim važnim međunarodnim pitanjima“ između SSSR-a i FNRJ 11. februara, susretima E. Kardelja i V. Molo-
} 
Jedan od ključnih dokumenata koji omogućava nijansiraniji uvid u pitanje odustajanja od trgovinskih pregovora za 1948. godinu jesu „Pitanja za pregovore sa zamenikom ministra spoljne trgovine Jugoslavije gdinom CRNOBRNjOM koji se nalazi u Moskvi“ koje je sastavio I. Semičasnov (sastavljen 20. 2., a zaveden pod 21. 2. 1948). Što se ,uzajamnih isporuka robe za 1948. god.“ tiče, navedeno je da se u slučaju da B. Crnobrnja postavi pitanje o datumu dolaska jugoslovenske trgovinske delegacije u Moskvu, ukaže da je po važećem Protokolu ostalo da se isporuči sovjetske robe u vrednosti od 26,8 miliona dolara, odnosno jugoslovenske u vrednosti od 31,7 miliona dolara. Kako su ove količine ,značajne“", sovjetski stav je bio da su obe strane dužne da preduzmu napore da bi ispunile svoje obaveze u predviđenom roku (do kraja maja 1948). Takođe, navedeno je da MST SSSR-a ,nema za sada preciznih podataka o izvoznim mogućnostima za celu 1948. godinu, pri čemu se za takve proizvode kao što su crni metali, pamuk i naftni derivati, predviđaju velike teškoće“. Zbog ovoga, navodi se dalje, sovjetsko Ministarstvo ,sada nema mogućnosti da vodi pregovore o dodatnim uzajamnim isporukama za 1948. godinu“ i u vezi sa tim ,pitanje o roku dolaska jugoslovenske trgovinske delegacije treba razmotriti naknadno“. Istaknuto je da takva ,izjava“ nije protivrečna uslovima Sporazuma o robnom prometu i plaćanjima od 5. jula 1947, ,u kojem rok za usaglašavanje dodatnih spiskova [robe za uzajamne isporuke] nije određen“. ${ }^{38}$ Značaj ovog dokumenta je što nam pruža uvid u to kako su ljudi iz ,ekonomskog aparata“ gledali na pregovore u ovom periodu kada je politika već uveliko uzela maha. Da je politika odnela prevagu, govori nam to što se ovi stavovi znatno razlikuju u odnosu na one iznete na prvom sastanku kod Mikojana. Od posebnog značaja je to što je i ovako, od strane politike, oblikovan stav ljudi iz MST SSSR-a 20/21. februara, narednih dana dodatno pooštren - odustalo se od pregovora u toku 1948.

Kako od razgovora kod Mikojana 3. februara nije bilo nikakvog odgovora sovjetske strane o povećanju trgovinske razmene i potpisivanju novog protokola o robnoj razmeni za 1948, a prošlo je gotovo 20 dana, ambasador Popović je sa

tova i definitivnom skidanju sa dnevnog reda pitanja ,zajma od 60 mil. dolara u zlatu Jugoslaviji“: Југословенско-совјетски односи 1945-1956, 250-254, док. 113-116; С. Селинић, „Југословенско-совјетски преговори...“, 603-607; V. Dedijer, Dokumenti 1948, I, 168-187; Isti, Novi prilozi za biografiju Josipa Broza Tita, III, 282-300; M. Đilas, Vlast i pobuna, 134141; Isti, Razgovori sa Staljinom, 110-119; E. Kardelj, n. d., 111-120; L. Gibianskii, „The Soviet Bloc and the Initial Stage of the Cold War: Archival Documents on Stalin's Meetings with Communist Leaders of Yugoslavia and Bulgaria, 1946-1948“, Cold War International History Project Bulletin, no. 10, (1998), 112-113, 115-117, 128-134; Л. Я. Гибианский, „К истории советско-югославского конфликта 1948-1953...”, I, 12-23; Исти, „К истории советскоюгославского конфликта 1948-1953...“, II, Славяноведение, но. 4, (1991), 4-36; Исти, „К истории советско-югославского конфликта 1948-1953...“, III, Славяноведение, но. 1, (1992), 42-56; Исти, „К истории советско-югославского конфликта 1948-1953...“, IV, Славяноведение, но. 3, (1992), 35-51; Георги Димитров, Дневник (9 март 1933-6 февруари 1949) (София: Университетско издателство „Св. Климент Охридски“, 1997), 596-603; А. С. Аникеев, „Югославия в годы конфликта с СССР...“, 26-27.

38 РГАЭ, Ф. 413, Оп. 24, Д. 4327, Л. 10-13, Вопросы к переговорам с находящимся в Москве Заместителем Министра Внешней Торговли Югославии г-ном ЦРНОБРНЯ, И. Семичастнов, 21. 2. 1948. 
Crnobrnjom i Žibernom 21. februara posetio A. D. Krutikova, ,prvog zamenika Mikojana“. Na početku razgovora jugoslovenski ambasador je istakao „da se stvari ne kreću sa mrtve tačke, da se nije još pristupilo radu jer nije dat principijelan odgovor sovjetske strane“. Na prvom mestu Popović je tražio „odgovor na naš predlog uzajamnih isporuka do kraja 1948.“, uz napomenu da jugoslovensku stranu „naročito [...] interesuje odgovor po metalima“. Pored „crnih metala“, posebno su pomenuti pamuk, nafta i naftni derivati, za koje su tražene „dopunske količine“ na razgovoru sa Mikojanom (19. 1.). „U ime vlade“, Mikojanov zamenik je rekao da su ,prostudirali“ jugoslovenske zahteve i da ,Za sada za period trajanja postojećeg Protokola o isporukama robe ništa ne možemo dati. Ne može se računati na nikakvo povećanje isporuka više onoga što je utvrđeno u ugovorima." Na pitanje da li se može računati na ,povećanje isporuka pomenutih artikala posle isteka postojećeg protokola koji važi do 31. maja ov. god.“, Krutikov je rekao: „Za sledeću godinu (ugovornu) isto tako ne možete računati na neke bitne promene, na neka bitna povećanja“. Odnosno, kako je Popović telegrafisao Titu, da „ne možemo računati u toku jednogodišnjeg perioda 1948-1949 na veći obim razmene po ovim artiklima nego što je bio u toku 1947-1948“. Sa jugoslovenske strane je istaknuto ,šta za nas znači takav njihov postupak“ i zatraženo objašnjenje. I ovom prilikom je naglašeno pitanje „,crnih metala“, ambasador je posebno pitao „,da li su oni (Sovjeti) vodili računa o našim potrebama po metalu i tačno izučili svoje mogućnosti isporuka“. Krutikov je rekao „da su oni deficitni u ovim artiklima i da ih kupuju na trećim tržištima“, da su „unutrašnje potrebe vrlo velike“ $i$ da „nisu dodeljeni takvi eksportni fondovi“. Napomenuo je da „ovaj kriterijum važi za sve susedne zemlje kojima se neće u ovoj godini povećavati kontingenti metala, pamuka i nafte“. Navodeći da „SSSR sam kupuje metale“, Krutikov je istakao da su Belgiji prodali žito za metal, a da su Rumuniji „dodelili nešto više metala ali zato da smo od njih dobili cevi za bušenje nafte u kojima vlada veliki deficit“".

Pitanje dolaska jugoslovenske delegacije Krutikov je dočekao gotovo sa čuđenjem, navodeći da mu ,ništa [...] nije poznato o dolasku delegacije“. Posle podsećanja jugoslovenskog ambasadora da je Mikojan dao „saglasnost“ i da je „šta više“ bio određen i „konkretan datum t. j. oko 10 februara“, kao i da je jugoslovenska delegacija „već predala vize na oformljavanja““ ${ }^{39}$ Krutikov je rekao da će se konsultovati sa Mikojanom i uskoro dati odgovor. Propratna pitanja i način na koji ih je V. Popović postavljao, pre odgovora Krutikova, kao da govore da su Jugosloveni očekivali duže odlaganje početka pregovora: „Možda smatrate da sada nije povoljan moment za dolazak naše delegacije u Moskvu? Možda zbog drugih delegacija koje se sada nalaze u Moskvi?" Kao da su se Jugosloveni pomirili sa dotadašnjim razvojem situacije i očekivali duže odlaganje, kao da im je jedino bilo važno da se samo „najhitnije informišu“ u slučaju da je

\footnotetext{
${ }^{39} \mathrm{Na}$ jugoslovenskoj strani sve je bilo spremno za otpočinjanje pregovora - J. B. Tito je dao saglasnost za sastav delegacije za pregovore koji je 17. februara predložio ministar spoljne trgovine Milentije Popović. Na čelu delegacije je trebalo da bude M. Popović, a za „zamenika šefa delegacije“ određen je B. Crnobrnja. Opširnije: AJ, fond 50, Predsedništvo Vlade FNRJ, fascikla 64, arhivska jedinica 139, 493-495, Rešenje o sastavu delegacije FNRJ za trgovinske pregovore sa SSSR.
} 
„došlo do promene“ u sovjetskoj odluci, nego da insistiraju da pregovori što pre počnu. Posle razgovora ambasador Popović je javio Titu: „Očevidno oni nisu raspoloženi da vode sada trg. pregovore sa nama“. Jugoslovenska beleška sa razgovora i telegram koji je V. Popović poslao Titu ukazuju da je jugoslovenske predstavnike više pogodio negativan odgovor o pitanju povećanja robne razmene, nego neodređen odgovor o početku novih trgovinskih pregovora. ${ }^{40}$

Ako je pitanje povećanja isporuka proizvoda koji su bili neophodni Jugoslaviji skinuto sa dnevnog reda na sastanku 21. februara, drugo ključno pitanje Crnobrnjine ,misije“ - da ,izvrši sve pripremne radnje, preda kontigentne liste i utvrdi tačan dan dolaska [jugoslovenske] delegacije“" - takođe je rezultiralo negativnim ishodom pet dana kasnije, 26. februara. Tada je Krutikov, posle konsultacije sa Mikojanom, saopštio Crnobrnji da se ,situacija izmenila“, da sovjetske „ogromne unutrašnje potrebe ne dozvoljavaju da u ovoj godini povećamo naše eksportne fondove“, da su ,podrobno izučili“" svoje izvozne mogućnosti i ,došli do zaključka da pored onoga što je već ugovoreno ništa više dodati ne možemo. Pitanje povećanja obima naših uzajamnih isporuka možemo razmotriti tek za 1949. g. Prema tome mi ćemo ispuniti obaveze koje imamo na osnovu postojećeg Sporazuma o uzajamnim isporukama i na osnovu Kreditnog Sporazuma. Što se tiče isporuka za 1949. g. razgovarati ćemo kasnije." Saslušavši ovo, Crnobrnja je ponovo pitao da li se izjava o ,nemogućnosti povećanja uzajamnih isporuka“ odnosi i na drugu polovinu 1948, dodajući: „Možda će u drugom polugodištu MST SSSR moći da izdvoji dodatnu robu za trgovinu sa Jugoslavijom“. Krutikov je ,još jednom rekao“ da ni u drugoj polovini godine „neće imati mogućnosti da povećaju uzajamne isporuke robe, preko količina predviđenih Sporazumom od 5.VII.47 g“. Posle ovako ,izričitog“ ponavljanja pitanja, Crnobrnja je konstatovao: „Ovo znači da između nas u drugoj polovini 1948. g. neće postojati Sporazum o uzajamnim isporukama robe i da će doći do prekinuća u razmeni robe“. Krutikov se držao argumentacije iznete na prethodnom sastanku - „da se ispunjenje postojećeg Sporazuma odvija sporo“ i da ,ako produžimo takvim tempom Sporazum će se ispunjavati još u toku 10 meseci“, a naveo je i da ,osim toga [...] mi imamo po drugim Sporazumima raznih obostranih obaveza tako da će isporuka među nama ipak biti“. Crnobrnja je podsetio na prethodnu ,,principijelnu saglasnost ministra Mikojana“ $\mathrm{i}$ istakao da ovo dovodi Jugoslaviju u ,vrlo ozbiljnu situaciju“ i ,da smo prosto izgubili dva meseca u kojima bi bili poduzimali mere da smo znali za ovakav njihov stav“. Osporavao je sovjetski argument o kašnjenju isporuka, navodeći da su se jugoslovenske isporuke značajno povećale u toku januara i februara (u vrednosti oko 6 miliona mesečno, u odnosu na dotadašnji prosek od 3 miliona) i , da bi one bile još

\footnotetext{
${ }^{40}$ РГАЭ, Ф. 413, Оп. 24, Д. 4322, Л. 158-160, Запись беседы заместителя министра внешней торговли Союза ССР тов. Крутикова А. Д. с послом Югославии в СССР Г-ном Поповичем, состоявшейся 21 февраля 1948 г; АJ, 9-190, Beleška sa sastanka održanog 21. februara 1948. u Minvneštorgu, Viktor Žiberna, 23. 2. 1948; AJ, fond 507-IX, CK SKJ - Međunarodna komisija, 119/I-41a, Telegram ambasadora V. Popovića - J. B. Titu, 21. 2. 1948; AJ, KMJ, I-3-b/651, Telegram ambasadora V. Popovića - J. B. Titu, 22. 2. 1948; Југословенско-совјетски односи 1945-1956, 257-258, док. 119.
} 
i veće da nije bilo sa Sovjetske strane otkazano nekoliko brodova“, da „baš ovaj čas leži u našim lukama robe za nekoliko miliona dolara i da čeka na brodove koje su Sovjeti dužni da dadu“, da su ,preduzete sve mere da budu tempi izvoza pojačani“", da „možemo garantirati da ćemo sve naše obaveze, sa iznimkom po kudelji, na vreme izvršiti“ i da ,iza našeg predloga o proširenju razmene stoji naša Vlada koja garantuje da će sve obaveze koje primimo biti izvršene“. Uz „Pitanja za pregovore sa zamenikom ministra spoljne trgovine Jugoslavije gdinom CRNOBRNjOM koji se nalazi u Moskvi“, reči Krutikova „evo ja sam na pr. tek danas dobio definitivan odgovor po tom pitanju. I mi nismo znali ranije da ćemo Vam dati takav odgovor", dodatno potvrđuju da odluka o odustajanju od trgovinskih pregovora za 1948. nije potekla iz sovjetskog Ministarstva spoljne trgovine, već je politika ta koja je presudno uticala na ekonomiju. Rečeno u razgovoru i ,potvrdan“ odgovor Krutikova na Crnobrnjino pitanje „da li se možemo vratiti nazad“, učinili su dalji boravak pomoćnika ministra spoljne trgovine FNRJ u Moskvi suvišnim. U narednim danima on je obavio još dva sastana$\mathrm{ka}-\mathrm{u}$ noći 27/28. februara imao je dug razgovor sa Semičasnovim o novom sporazumu i različitim pitanjima u vezi sa „tehničkom pomoći“, a 2. marta razgovarao je sa Semičasnovim i Borisovim o „transportnim pitanjima“, ali je njegov „osnovni cilj“ bila ,želja da učini oproštajnu posetu pred odlazak“. Narednog dana, 3. marta 1948, Bogdan Crnobrnja je napustio sovjetsku prestonicu i odleteo za Beograd. ${ }^{41} \mathrm{Za}$ razliku od bugarskog rukovodstva koje je posle „trojnog sastanka“" od 10. februara i potpisivanja protokola o obaveznom konsultovanju po međunarodnim pitanjima delovalo u skladu sa sovjetskim instrukcijama, Beograd je počeo „da deluje uprkos sovjetskim direktivama“ ${ }^{42}$ To očigledno nije moglo da prođe bez posledica.

Kakav je značaj sovjetsko odustajanje od povećanja isporuka i potpisivanja novog sporazuma imalo za Jugoslaviju? Svu težinu novonastale situacije Crnobrnja je predočio na sastancima sa Mikojanovim zamenicima. Krutikovu je 26. februara rekao: „Mi smo naš rad planirali u pretpostavci da ćemo osnovne artikle kao metale, naftine derivate i pamuk kupiti kod Vas. Vaš odgovor koji je dat tek danas dovodi nas u ozbiljnu situaciju jer smo u toj pretpostavci čekali samo oformljenje i utvrđivanje količine a da u međuvremenu nismo preduzimali posebnih koraka da se obezbedimo na drugoj strani." Posebno teška situacija je bila sa nedostatkom naftnih

\footnotetext{
${ }^{41}$ AJ, 9-190, Beleška sa sastanka održanog 26. februara 1948. g. u Minvneštorgu; РГАЭ, Ф. 413, Оп. 24, Д. 4322, Л. 161-163, Запись беседы Заместителя Министра Внешней Торговли Союза ССР тов. Крутикова А. Д. с Заместителем Министра Внешней Торговли Югославии г-ном Црнобрня состоявшейся 26 февраля 1948 года; АJ, КМJ, I-3-b/653, Izveštaj o toku pregovora sa SSSR-om, B. Crnobrnja, 3. 4. 1948; AJ, 9-190, Beleška sa sastanka sa Semičastnovim održanog 28. II. 1948; РГАЭ, Ф. 413, Оп. 24, Д. 4322, Л. 149-154, Запись беседы Заместителя Министра Внешней Торговли Союза ССР тов. Семичастнова И. Ф. с Заместителем Министра Внешней Торговли Югославии г-ном Црнобрня состоявшейся 27 февраля 1948 г; РГАЭ, Ф. 413, Оп. 24, Д. 4322, Л. 155-156, Запись беседы Зам. Министров Внешней Торговли СССР т. т. Семичастнова И. Ф. и Борисова С. А. с Зам. Министра Внешней Торговли Югославии г. Црнобрня 2 марта 1948 года.

${ }^{42}$ Opširnije: L. Gibianskii, „Sovjetsko-jugoslovenski sukob 1948...“, 41-42, 44-45.
} 
derivata - ,imamo po nekim asortimentima zaliha samo na 15 do 30 dana“ - i pretila je obustava ,,automobilskog saobraćaja“; a nedostatak pamuka je pretio da izazove zaustavljanje ,tekstilne industrije“. Kritično stanje je bilo i sa nedostatkom automobilskih guma, papira, celuloze, kugličnih ležajeva i crnih metala. Govoreći o „teškom stanju“ u kome se Jugoslavija našla, Crnobrnja je Semičasnovu napomenuo kako se ,jugoslovenska industrija do sada bazirala uglavnom na sovjetskim sirovinama i da je sada za njih veoma teško da nađu druge izvore snabdevanja i da je samim tim ugroženo ispunjenje petogodišnjeg plana“، 43

Kako su na jugoslovenskoj strani gledali na sovjetsku odluku? Na proširenom zasedanju Politbiroa CK KPJ 1. marta 1948. konstatovano je: „odnosi između nas i SSSR-a došli su u ćorsokak u poslednje vreme“. Sovjetsku odluku „da ne mogu s nama praviti trgovinski ugovor u maju, već možda u decembru“ Tito je okarakterisao sa: ,Vrše [...] ekonomski pritisak na nas. Treba da izdržimo taj pritisak. Ovdje se radi o nezavisnosti naše zemlje“. ${ }^{44}$ Iako je u narednom periodu na jugoslovenskoj strani sintagma ,ekonomski pritisak“ korišćena da se opišu različite mere $u$,hladnom ratu“ između dve države - od ovog odlaganja pregovora do potpune ekonomske blokade od strane SSSR-a i ,njegovih satelita“445 - zbog velikih unutrašnjih potreba Jugoslavije, prethodne sovjetske saglasnosti da se vode pregovori i posledica koje je odustajanje od istih imalo na jugoslovensku privredu, možda je bolje sovjetski postupak nazvati udarom. Jasna poruka jugoslovenskom rukovodstvu se mogla poslati i izvršiti konkretan pritisak i da se saopštilo da će se pregovori voditi po isteku važećeg protokola ili po njegovoj realizaciji. Izjava Krutikova od 26. februara bila je korak dalje u odnosu na takav pritisak.

Ishod razgovora Crnobrnje i Krutikova izazvao je veliku zabrinutost u jugoslovenskoj prestonici. Početkom marta u razgovoru sa sovjetskim ambasadorom, J. B. Tito je komentarisao izjavu Krutikova, ne krijući svoje nezadovoljstvo. Ambasador Lavrentjev je pribeležio da je Tito pokrećući ovo pitanje bio ,vidno uznemiren“, da je isticao da ,jugoslovenska vlada ne razume zašto Sovjetski Savez odbija da zaključi trgovinski sporazum sa Jugoslavijom, dok istovremeno sa drugim zemljama SSSR zaključuje takve sporazume“, da je više puta ponovio ,da je takva odluka Moskve neshvatljiva“ i ,nespojiva sa prijateljskim odnosima dve zemlje“ i da nas ,takav odnos prema Jugoslaviji vređa“. Tito je naveo da je ovakva odluka posebno „nejasna“ zbog toga što je saopštena ,jugoslovenskoj delegaciji nakon što je ona dva meseca boravila u Sovjetskom Savezu“. Ističući da je „Jugoslavija bila veran saveznik Sovjetskog Saveza za vreme rata i da je u Jugo-

${ }^{43}$ AJ, 9-190, Beleška sa sastanka održanog 26 februara 1948. g. u Minvneštorgu; РГАЭ, Ф. 413, Оп. 24, Д. 4322, Л. 153-154, Запись беседы Заместителя Министра Внешней Торговли Союза ССР тов. Семичастнова И. Ф. с Заместителем Министра Внешней Торговли Югославии г-ном Црнобрня состоявшейся 27 февраля 1948 г.

${ }^{44}$ Opširnije: Zapisnici sa sednica Politbiroa Centralnog komiteta KPJ (11. jun 1945-7. jul 1948), prir. B. Petranović (Beograd: Arhiv Jugoslavije, Službeni list SRJ, 1995), 236-247; Југословенско-совјетски односи 1945-1956, 260-264, док. 121; V. Dedijer, Novi prilozi za biografiju Josipa Broza Tita, III, 303-308; Isti, Dokumenti 1948, I, 191-195; S. Vukmanović Tempo, n. d., 25-27; M. Đilas, Vlast i pobuna, 142-144.

${ }^{45}$ AJ, KMJ, I-3-b/673, Faze politike SSSR i njegovih satelita prema Jugoslaviji, 30. 8. 1952. 
slaviji demokratija učvršćena jače no u drugim zemljama Istočne Evrope“, Tito je ocenio da će nezaključivanje trgovinskog ugovora između dve države ,biti nemoguće objasniti jugoslovenskom narodu“. Napominjući da će se ,prekid trgovine““ sa SSSR-om ,,veoma odraziti na ispunjenje od strane Jugoslavije petogodišnjeg plana“, Tito je istakao i da će to ,nesumnjivo [...] otežati Jugoslaviji obavljanje trgovinskih plaćanja“, da Jugoslavija zbog nedostatka ,potrebnih deviza“ neće moći da plaća izdržavanje učenika u SSSR-u i da će morati da smanji njihov broj; takođe, pomenuo je da će ova odluka uticati i na ,vojne isporuke“, jer se „nafta $\mathrm{i}$ teretna vozila za armiju isporučuju u skladu sa trgovinskim sporazumom“. Tito je govoreći da su možda u Moskvi ,nečim nezadovoljni Jugoslavijom“ istakao da „čak u istoj porodici dolazi do svađa između dva brata“ i molio da se sovjetska vlada obavesti o ovome i da on ovim ,ppostavlja ovo pitanje zvanično“. ${ }^{46}$

Usledila je prepiska u kojoj je Molotov negirao istinitost tvrdnje da je Krutikov dao izjavu da do potpisivanja protokola o uzajamnim isporukama $\mathrm{u}$ 1948. godini neće doći, govoreći da se „očigledno, radi o nesporazumu ili o kleveti“. Ministar inostranih poslova SSSR-a je naveo i da rok sporazuma za 19471948. ističe 31. maja i ,verovatno će se do tada morati zaključiti novi sporazum za 1948-1949. g. “" ${ }^{\text {‘7 }}$ U odgovoru na ovo Tito je naveo da je jugoslovenska strana izvela zaključak na osnovu izveštaja zamenika ministra spoljne trgovine Crnobrnje o razgovoru 26. februara i istakao da ,vlada FNRJ sa zadovoljstvom prima na znanje Vaš telegram u kojem Vi izjavljujete da je Sovjetska vlada spremna da zaključi trgovinski protokol za period 1948-49.“. Jugoslovenski maršal je na kraju dodao da isključuje svaku mogućnost da se radilo o kleveti, s obzirom na argumente koji su izneti, a zasnivaju se na Crnobrnjinom izveštaju. ${ }^{48}$

Ovo pitanje se pominjalo i u poznatom pismu od 27. marta koje je CK Svesavezne komunističke partije (boljševika) (SKP(b)) uputio CK KPJ i tom prilikom je negirana istinitost tvrdnje da je Krutikov dao izjavu koja mu se pripisuje („drug Krutikov kategorički poriče ono što mu se pripisuje“). ${ }^{49}$ U odgovoru na ovo, u pismu od 13. aprila 1948, jugoslovenska strana je ostala na svom stanovištu, a tačka na pitanje stavljena je, jednostrano, u pismu CK SKP(b)-a od 1. maja 1948. kada je, između ostalog, rečeno: „Mi smo već nekoliko puta objašnjavali jugoslovenskim drugovima da drug Krutikov odriče izjavu koja mu se pripisuje. Mi smo objašnjavali takođe da sovjetska vlada nije postavila pitanje prekidanja trgovačkih pregovora i trgovačkih operacija s Jugoslavijom. Mi zato ovo pitanje smatramo iscrpljenim i nemamo nameru da se više na njega vraćamo“. 50

Već imajući samo u vidu sistem odlučivanja u Sovjetskom Savezu, subordinaciju i birokratizovanost državnog aparata, jasno je da Krutikov nije mogao tako nešto da izjavi na svoju ruku, pa posle da negira. Ako je nedoumice

\footnotetext{
${ }^{46}$ Југословенско-совјетски односи 1945-1956, 266-267, док. 123.

47 Исто, 268, док. 124.

${ }^{48}$ Исто, 269-270, док. 125; Советский фактор в Восточной Европе 1944-1953. В двух томах. Документыл. Т. 1: (1944-1948), Т. 2: (1949-1953), Отв. ред. Волокитина Т.В, (Москва: РОССПЭН, 1999), 1/567-568, док. 197.

49 Југословенско-совјетски односи 1945-1956, 284, док. 132.

50 144, Исто, 295, 334, док. 136.
} 
uopšte moglo biti, ovo pitanje u potpunosti razrešavaju zapisnici sa razgovora koji do sada nisu korišćeni u istoriografiji. Jugoslovenska i posebno sovjetska beleška sa razgovora nedvosmisleno pokazuju da je Krutikov 26. februara izjavio da do pregovora i zaključenja protokola o uzajamnim isporukama za 1948. neće doći. ${ }^{51}$ Zbog čega je onda sovjetska strana negirala izjavu Krutikova? Možemo se složiti sa mišljenjem Čedomira Štrpca, koji smatra da je poricanje izjave Krutikova ,verovatno bilo motivisano željom da se sa sovjetske strane skine svaka odgovornost za pogoršanje sovjetsko-jugoslovenskih odnosa i da se za to [...] učini isključivo odgovornim jugoslovensko rukovodstvo“. ${ }^{2} \mathrm{U}$ prilog ovome govori $\mathrm{i}$ to što se sovjetska strana u narednom periodu, kada je sukob uveliko počeo, držala ,verzije“ događaja prema kojoj je „u martu o. g. s naše strane data saglasnost Jugoslovenima za pregovore o uzajamnim isporukama robe u junu mesecu o. g., jer je 1. juna isticao rok važenja Protokola Sporazuma od 5. juna 1947.“, a „Jugosloveni su odustali od pregovora za novi Sporazum“. 53

\section{REFERENCE}

- Anikeev, Anatolij S. Kak Tito ot Stalina ushel: Yugoslaviya, SSSR i SShA v nachal'nyj period «xolodnoj vojny» (1945-1957). Moskva: Institut Slavyanovedeniya RAN, 2002.

- Anikeev, Anatolij S. „Albaniya v politike Yugoslavii i SSSR v pervye poslevoennye gody po sovetskim diplomaticheskim dokumentam“. U: Oslobođenje Beograda 1944. Zbornik radova. Glavni i odgovorni urednik Aleksandar Životić, 469-489. Beograd: Institut za noviju istoriju Srbije, 2010.

- Anikeev, Anatolij S. „Yugoslaviya v gody konflikta s SSSR i stranami «narodnoj demokratii»". U: Moskva i Vostochnaya Evropa. Sovetsko-yugoslavskij konflikt i strany sovetskogo bloka. 1948-1953 gg. Ocherki istorii. Otv. red. A. S. Anikeev, 15-104. Moskva: Institut slavyanovedeniya RAN, SanktPeterburg: Nestor-Istoriya, 2017.

- Crnobrnja, Stanko. „Bogdan Crnobrnja Tolja“. U: Neočekivana promjena. Kako je stvoren Pokret nesvrstanih. Dnevnički zapisi Bogdana Crnobrnje iz 1961. godine. Urednik S. Crnobrnja, 13-18. Beograd: Muzej istorije Jugoslavije, 2016.

- Dedijer, Vladimir. Izgubljena bitka J. V. Staljina. Beograd: Izdavačka organizacija ,Rad“, 1978.

- Dedijer, Vladimir. Dokumenti 1948. Knjiga prva. Beograd: Izdavačka radna organizacija „Rad“, 1979.

${ }^{51}$ AJ, 9-190, Beleška sa sastanka održanog 26 februara 1948. g. u Minvneštorgu; РГАЕ, Ф. 413, Оп. 24, Д. 4322, Л. 161-163, Запись беседы Заместителя Министра Внешней Торговли Союза ССР тов. Крутикова А. Д. с Заместителем Министра Внешней Торговли Югославии г-ном Црнобрня, состоявшейся 26 февраля 1948 года.

52 Čedomir Štrbac, Jugoslavija i odnosi između socijalističkih zemalja. Sukob KPJ i Informbiroa (Beograd: Prosveta, 1984), 90.

53 Российский государственный архив социально-политической истории, Фонд 84 (Личный фонд А. И. Микояна), Оп. 1, Д. 32, Л. 88, А. Микоян, Сталину И. В., 24. 7. 1948. 
- Dedijer, Vladimir. Novi prilozi za biografiju Josipa Broza Tita. Treći tom. Beograd: Izdavačka radna organizacija „Rad“, 1984.

- Dimić, Ljubodrag. Jugoslavija i Hladni rat. Ogledi o spoljnoj politici Josipa Broza Tita (1944-1974). Beograd: Arhipelag, 2014.

- Dimitrov, Georgi. Dnevnik (9 mart 1933-6 fevruari 1949). SofiJa: Universitetsko izdatelstvo „Sv. Kliment Ohridski“, 1997.

- Đilas, Milovan. Razgovori sa Staljinom. Beograd: Književne novine, 1990.

- Đilas, Milovan. Vlast i pobuna. Beograd: Književne novine, 1991.

- Gibianskij, Leonid Yanovich. „K istorii sovetsko-yugoslavskogo konflikta 1948-1953: Sekretnaya sovetsko-yugoslavo-bolgarskaya vstrecha v Moskve 10 fevralya 1948 goda“, I. Slavyanovedenie, no. 3, (1991), 12-23.

- Gibianskij, L. Ya. „K istorii sovetsko-yugoslavskogo konflikta 1948-1953: Sekretnaya sovetsko-yugoslavo-bolgarskaya vstrecha v Moskve 10 fevralya 1948 goda“, II. Slavyanovedenie, no. 4, (1991), 4-36.

- Gibianskij, L. Ya. „K istorii sovetsko-yugoslavskogo konflikta 1948-1953: Sekretnaya sovetsko-yugoslavo-bolgarskaya vstrecha v Moskve 10 fevralya 1948 goda“, III. Slavyanovedenie, no. 1, (1992), 42-56.

- Gibianskij, L. Ya. „K istorii sovetsko-yugoslavskogo konflikta 1948-1953: Sekretnaya sovetsko-yugoslavo-bolgarskaya vstrecha v Moskve 10 fevralya 1948 goda“, IV. Slavyanovedenie, no. 3, (1992), 35-51.

- Gibianskii, Leonid. „The Soviet Bloc and the Initial Stage of the Cold War: Archival Documents on Stalin's Meetings with Communist Leaders of Yugoslavia and Bulgaria, 1946-1948“. Cold War International History Project Bulletin, no. 10, (1998), 112-134.

- Gibianskii, Leonid. „Sovjetsko-jugoslovenski sukob 1948: istoriografske verzije i novi arhivski izvori“. U: Jugoslavija v hladni vojni, Zbornik z znanstvenega posveta Jugoslavija v hladni vojni, Ljubljana, 8.-9. maja 2000. Uredniki Jasna Fischer, Aleš Gabrič, Leonid J. Gibianskii, Edith S. Klein i Ronald W. Preussen, 27-47. Ljubljana: Inštitut za novejšo zgodovino, Toronto: University, 2004.

- Jugoslovensko-sovjetski odnosi 1945-1956. Zbornik dokumenata. Priredili Ljubodrag Dimić, Miladin Milošević, Đorđe Borozan, I. V. Buharkin, L. V. Vnukova, J. A. Zelenko, M. K. Kravčenko i V. A. Soljanski. Beograd: Ministarstvo spoljnih poslova Republike Srbije, 2010.

- Kardelj, Edvard. Borba za priznanje $i$ nezavisnost nove Jugoslavije 19441957. Sećanja. Beograd: NIRO Radnička štampa, Ljubljana: Državna založba Slovenije, 1980.

- Ninković, Momir. „Neuspešni pregovori o organizaciji jugoslovensko-sovjetskih mešovitih društava (1945-1947)“. Tokovi istorije, br. 2, (2015), 129-152.

- Ninković, Momir. „Uspostavljanje i odvijanje redovnih ekonomskih odnosa između Jugoslavije i Sovjetskog Saveza 1945. godine“. U: 1945. Kraj ili novi početak?, Tematski zbornik radova. Glavni i odgovorni urednik Zoran Janjetović, 497-529. Beograd: Institut za noviju istoriju Srbije, Muzej žrtava genocida, 2016.

- Petranović, Branko. „Pomoć UNRE Jugoslaviji“. U: Istorija 20. veka. Zbornik radova. Odgovorni urednik Dragoslav Janković, 163-224. Beograd: ISI, 2/1961. 
- Petranović, Branko. Istorija Jugoslavije. Treća knjiga. Socijalistička Jugoslavija 1945-1988. Beograd: Nolit, 1988.

- Petranović Branko, i Sava Dautović. Velika šizma. Četrdesetosma. Podgorica: CID, 1999.

- Popović, Dušan. Letopis o Vlaovićima. III. Novi Sad: Agencija MiR, 2006.

- Popović, Nikola B. „Sukob Tito-Staljin u svetlu sovjetizacija Istočne Evrope“. U: Zbornik radova sa međunarodnog okruglog stola Tito-Staljin. Glavni i odgovorni urednik Miladin Milošević, 95-108. Beograd: Arhiv Srbije i Crne Gore, 2007.

- Selinić, Slobodan. „Jugoslovensko-sovjetski pregovori, decembar 1947-februar 1948. godine. Prilog proučavanju jugoslovensko-sovjetskog sukoba 1948. godine“. U: Međunarodni naučni skup Braničevo u istoriji Srbije. Zbornik radova III. Sveska 6. Glavni i odgovorni urednik Dragan Aleksić, 595-614. Požarevac: Istorijski arhiv Požarevac, Beograd: Institut za noviju istoriju Srbije, 2008.

- Selinić, Slobodan. „Jugoslovenska ambasada u SSSR-u 1944-1949. Političke prilike i partijski život“. U: Srbija i Rusija 1814-1914-2014. Međunarodni naučni skup 13-14. oktobar 2014. Urednik Mihailo Vojvodić, 273-291. Beograd: Srpska akademija nauka i umetnosti, 2016.

- Sovetskij faktor v Vostochnoj Evrope 1944-1953. V dvux tomax. Dokumenty. T. 1: (1944-1948), T. 2: (1949-1953). Otv. red. Volokitina T. V. Moskva: ROSSPE'N, 1999.

- Šaškor, Ines. „Crnobrnja, Bogdan“. U: Enciklopedija Jugoslavije, 3, Crn-Đ, 57. Zagreb: Jugoslavenski leksikografski zavod Miroslav Krleža, 1984.

- Štrbac, Čedomir. Jugoslavija i odnosi između socijalističkih zemalja. Sukob KPJ i Informbiroa. Beograd: Prosveta, 1984.

- Tarabić, Joco. „Crnobrnja Bogdan“. U: Vojna enciklopedija, Drugo izdanje, 2, Brdo-Foa, 210. Beograd: izdanje Redakcije Vojne enciklopedije, 1971, 210.

- Terzić Milan, Mihajlo Basara, i Dmitar Tasić. „Uvod“. U: Informbiro i Jugoslovenska (narodna) armija. Zbornik dokumenata. Priredili Milan Terzić, Mihajlo Basara i Dmitar Tasić, 9-58. Beograd: Službeni glasnik, 2015.

- Tripković, Đoko. „Iza gvozdene zavese. Početak i eskalacija sukoba TitoStaljin prvih meseci 1948“. Istorija 20. veka, br. 1, (1996), 89-99.

- Yugoslaviya $v$ XX veke. Ocherki politicheskoj istorii. Otvetstvennyj redaktor K. V. Nikiforov. Moskva: InSlav, Indrik, 2011.

- Vukmanović-Tempo, Svetozar. Revolucija koja teče. Memoari. Knjiga četvrta. Zagreb: Globus, 1982.

- Zapisnici sa sednica Politbiroa Centralnog komiteta KPJ (11. jun 1945-7. jul 1948). Priredio Branko Petranović. Beograd: Arhiv Jugoslavije, Službeni list SRJ, 1995.

- Životić, Aleksandar. Jugoslavija, Albanija i velike sile (1945-1961). Beograd: Arhipelag, Institut za noviju istoriju Srbije, 2011.

- Životić, Aleksandar. Jugoslovensko-sovjetske vojne suprotnosti (1947-1957). Iskušenja savezništva. Beograd: Arhipelag, Institut za noviju istoriju Srbije, 2015. 
MA MOMIR NINKOVIĆ, PhD Student

Faculty of Philosophy, University of Belgrade

Belgrade, Republic of Serbia

momirninkovic22@gmail.com

\section{THE MISSION OF BOGDAN CRNOBRNJA IN MOSCOW AND THE QUESTION OF ABANDONING TRADE NEGOTIATIONS FOR 1948}

\section{Summary}

At the end of 1947, the Yugoslav side launched issues of expanding "trade" between Yugoslavia and the Soviet Union and signing a new protocol on mutual supplies for 1948. Deputy Minister for Foreign Trade FNRJ B. Crnobrnja, in early 1948, was supposed to deliver the Yugoslav demands in Moscow and perform all "preparatory" actions to start the negotiations. At a meeting with A. Mikoyan on January 19, the Soviet Minister agreed to deliver most of the products for which the Yugoslav side showed interest and agreed that the trade negotiations would begin "around" 10th of February. Although the beginning of the talks was promising, since the end of January, because of the problems in the political relations of the two countries, the Soviet side began delaying further talks. As the Yugoslav leadership did not react after the criticism in the way the Soviets expected, on February 21 it was announced to Crnobrnja that Yugoslavia could not count on any increase in the deliveries and on February 26, "First Deputy of Mikoyan" A. Krutikov said that protocol on mutual supplies will not be signed in the 1948. The Soviets explained this decision by Yugoslav delay in delivering supplies under the 1947 Protocol and lack of its own export opportunities. On the Yugoslav side, this decision was interpreted as "economic pressure". Because of the consequences it had on the Yugoslav economy, it can be characterized as the first serious blow to Yugoslavia by "economic" measures. Later, the Soviet denial of Krutikov's statement of February 26 was motivated by the intention to withhold any responsibility for deteriorating relations between the two countries.

KEYWORDS: Yugoslavia, Soviet Union, 1948, trade negotiations, foreign trade, Bogdan Crnobrnja, Milovan Djilas, Anastas Ivanovich Mikoyan, Alexey Dmitriyevich Krutikov 